\title{
Monitoring activities in the Federal Republic of Germany pursuant to international conventions and national legislation*
}

\author{
Dieter P. Kohnke \\ Deutsches Hydrographisches Institut; Bernhard-Nocht-Straße 78, D-2000 Hamburg 36, \\ Federal Republic of Germany
}

\begin{abstract}
The main activities of the Federal Republic of Germany regarding the monitoring of the pollution of the North Sea and the Baltic Sea are described. Reference is also made to research projects concerned with the investigation of the processes of transportation and transformation of harmful substances in the marine ecosystem. Political conclusions drawn by the Federal Government are mentioned. Environmental protection measures are only dealt with marginally; combatting measures are not dealt with.
\end{abstract}

\section{INTRODUCTION}

Over the past few decades, both the North Sea and the Baltic Sea have become increasingly polluted ocean areas. Being regions of rich resources, of extensive seaside resorts and recreation areas, they have now become subject to intensified protection endeavours. Their capacity for absorbing the liquid and solid wastes of the bordering countries was traditionally viewed as being unlimited. However, in the early 1950s the nations became aware of an impaired quality of the marine environment.

Certain protection measures were to be taken, because both regions lack a sufficient exchange of water masses with neighbouring ocean basins. This lack causes pollutants to remain there for extended periods of time.

The continuing transport of pollutants by rivers or through the atmosphere may lead to increasing concentration levels in these regions. For example, the larger rivers presently discharge into the high seas four times the amount of nitrogen compounds and seven times the amount of phosphorus, compared to that caused by natural erosion in former times (Gerlach, 1987).

It is evident that pollution of the marine environment is an international problem which cannot be resolved by national regulations only. The requirement for internationally co-ordinated measures for the protection of the sea became pressing in the early fifties. However, it has taken about twenty years to reach international conventions for monitoring and preventing marine pollution.

\footnotetext{
- Presented at the VI International Wadden Sea Symposium (Biologische Anstalt Helgoland, Wattenmeerstation Sylt, D-2282 List, FRG, 1-4 November 1988)
} 
This paper deals with environmental protection measures only marginally, and it does not go into combatting matters.

\section{NATIONAL MONITORING ACTIONS}

The main activities of the Federal Republic of Germany concerning the monitoring of the pollution of the North Sea and the Baltic Sea are:

(1) the "Gemeinsames Bund/Länder-Meßprogramm für die Nordsee" (BLMP: a joint measuring programme of Federal and State institutions in the North Sea);

(2) the monitoring programme of the Deutsches Hydrographisches Institut in the North Sea and the Baltic Sea;

(3) the biological monitoring programme of the Institut für Meereskunde at the University of Kiel in the Baltic Sea.

In addition to these long-term monitoring activities, research projects, such as ZISCH ("Zirkulation und Schadstoffumsatz in der Nordsee"/Circulation and "life cycle" of harmful substances in the North Sea) or the project "Eutrophication of the North Sea and the Baltic Sea", have been carried out.

\section{Bund/Länder-Meßprogramm (BLMP)}

The BLMP is primarily a monitoring programme for regular and long-term collection of the scientific data and fundamental information needed by Federal and State institutions to help assess the quality of the marine environment (Bundesminister für Umwelt, Naturschutz und Reaktorsicherheit, 1986). This includes knowledge about (1) the transport of substances and material into the coastal zones of the German Bight by rivers and near-coastal sewage discharge; (2) the distribution and whereabouts of substances; and (3) their impact on the water, sediment, and organisms. With the aid of this programme, a potential endangering of the marine environment is recognized earlier than before, thus helping to reduce emission.

The area of investigation comprises the territorial waters of the Federal Republic of Germany, adjacent parts of the high seas, and the estuaries of the rivers Ems, Weser, Elbe und Eider within their tidal ranges.

The BLMP includes physical and chemical analyses of water, sediment, and organism samples. The data are compiled by the Niedersächsisches Landesamt für Wasserhaushalt (NLW) in Hildesheim, and both the data and its interpretation are regularly published in a special report.

\section{The DHI Monitoring Programme}

The co-ordination and the implementation of scientific monitoring in the high seas was assigned to the Deutsches Hydrographisches Institut (DHI). However, that excluded the implementation of biological monitoring. The DHI monitoring programme is consequent to international conventions and national legislation related to the prevention of pollution of the marine environment. This includes

(a) the commitment to monitoring, pursuant to the Oslo-, Paris- and Helsinki Conventions as well as to the BLMP and various guidelines of the European Community $(\mathrm{EC})$; 
(b) the national Law on the tasks of the Federal Government for ocean shipping, according to which the $\mathrm{DHI}$, inter alia, must monitor the sea water for radioactivity and other pollutants (Seeaufgabengesetz);

(c) the national Law for the Precautionary Protection of the Population from Radioactive Loads (Strahlenschutzvorsorge-Gesetz, StrVG 1986);

(d) the interministerial agreement between the Bundesminister für Forschung und Technologie (BMFT), Bundesminister des Innern (BMI), Bundesminister für Ernährung, Landwirtschaft und Forsten, and the Bundesminister für Verkehr (BMV) for the implementation of a biological monitoring in the high seas (1985).

The monitoring activities of the DHI programme are concentrated on the German continental shelf. However, regular measurements are also carried out outside that region, because

- the German continental shelf is an open ecological system which is strongly influenced by processes in the North Sea and even in the northeastern Atlantic Ocean;

- our political standpoint and mode of action concerning the protection of the marine environment are not always in agreement with those of other states bordering the North Sea. Therefore, it is indispensible to take suitable measurements outside the German continental shelf, in order to get a full picture of the environmental conditions there.

The goals of the DHI monitoring are:

(A) The description of the distribution of substances or groups of substances:

- regional distribution;

- identification of regions with increased concentrations;

- identification of pollution sources.

(B) The assessment of the existing condition of a specific substance or group of substances:

- natural variability of the measured values;

- comparison with non-influenced regions;

- decisions on whether measures must be taken for areas with high concentrations, and whether measures which have already been taken have led to an improvement in environmental quality.

(C) Description of the temporal and spatial variation of the distribution of a substance or a group of substances (so-called trend monitoring).

The substances/variables measured are:

- nutrients and oxygen;

- heavy metals in sea-water and in the sediment;

- radioactivity;

- haloginated hydrocarbons;

- petroleum hydrocarbons;

- temperature and salinity.

The occurrence of oxygen depletion, particularly in the German Bight during calm weather conditions in summer, has given rise to co-ordinated measures of the DHI and other German institutes to monitor the oxygen concentration as permanently as possible.

The results of the DHI monitoring are published annually in the DHI series "Überwachung des Meeres" (cf. DHI, 1987, Teil I: Berichte; DHI, 1988, Teil II: Daten). 


\section{Biological Monitoring}

The biological monitoring in the Federal Republic of Germany is co-ordinated by the DHI.

Routine monitoring has not yet been fully developed for the North Sea, mainly due to the lack of international commitments and of sufficient staffing at the respective institutions. An excellent time series for physical, nutrient, and plankton data exists from the station "Helgoland Reede" of the Biologische Anstalt Helgoland (BAH). The BAH, under the Guideline of the EC (82/883/EWG), also monitors the variety of benthic species in and adjacent to the dumping area for dilute acids of the titanium dioxide production. The Bundesforschungsanstalt für Fischerei (BFA), under the same Guideline, examines fishes for diseases in the same area.

Other biological work of German institutions in the North Sea is carried out for research rather than for monitoring purposes. There is, however, a nation-wide consensus that "monitoring" ought not to be separated from "research". So, time series, test procedures, or assays originally designed for research, if suitable, are used for monitoring purposes as well. Results of the following long-term research projects are used for biological monitoring:

- phytoplankton and nutrient measurements at "Helgoland Reede";

- benthos (macro-zoobenthos) from the seaward side of the North Frisian Islands (particularly Sylt);

- fish diseases in the North Sea, particularly in the German Bight;

- malformation of fish embryos in the German Bight and adjacent regions.

The Federal Republic has recently reported to the Joint Monitoring Group (JMG) of the the Oslo- and Paris Commissions (OSPARCOM) about laboratory and in situ test procedures, and also about field monitoring programmes which are suitable for the detection of biological effects after a relatively short period of exposure.

The Baltic Sea situation is different from that of the North Sea. The Contracting Parties of the Helsinki Convention (1974) agreed to implement a biological monitoring programme in that region (Baltic Marine Environment Protection Commission, 1986).

An administrative agreement for the determination of scientific principles as well as for the collection and interpretation of data from a biological monitoring in the Baltic Sea was signed by the Federal Minister of Research and Technology (BMFT) and the Minister for Culture of Schleswig-Holstein in 1985. The Institut für Meereskunde in Kiel (IfMK) was assigned to carry out investigations on benthos and plankton, on behalf of the Federal Government. The IfMK collaborates with other institutions involved in the implementation of a biological monitoring, such as the DHI, the BAH, the BFA, and the Umweltbundesamt (UBA). Experts of the IfMK represent the Federal Republic of Germany in HELCOM working groups. The investigations are implemented according to methods on which international agreement has been reached. 


\section{NATIONAL RESEARCH PROJECTS RELATED TO OCEAN MONITORING}

\section{ZISCH (Circulation and "life cycle". of harmful substances in the North Sea)}

The project aims at a quantitative determination of the balance of important pollutants discharged into the North Sea. This includes toxic substances, such as heavy metals and organohalogens, as well as nutrients which are supplied in excessive quantities. Knowing the anthropogenic sources, both paths of transport and the whereabouts of critical contaminants have been investigated and their balance has been calculated.

The project consisted of physical, chemical, and biological components which were closely interconnected. The field programme was supported by numerical models to simulate the input, transport and reactions of substances in the coupled system atmosphere/ocean.

The Institut für Meereskunde in Hamburg (IfMHH) was charged with the implementation of ZISCH. For those parts where either expertise or the capacity of the University of Hamburg were insufficient, collaboration was sought from other German institutions (Alfred-Wegener-Institut für Polar- und Meeresforschung, Bremerhaven; Technische Universität, Hamburg-Harburg; Rheinisch-Westfälische Technische Hochschule, Aachen; DHI; BAH).

The principle item of this project is formed by two surveys of the entire North Sea with three ships (summer 1986 and winter 1986/87), when physical, chemical, and biological variables were measured simultaneously. These measurements constitute a unique data set for the North Sea which is of equal importance to ocean science and people concerned with the protection of the marine environment.

\section{Eutrophication of the North Sea and the Baltic Sea}

Extreme phytoplankton blooms, very low concentrations of oxygen, and subsequent mortality in fishes (e.g. in 1981 and in 1982) led to a research project to investigate the eutrophication of the North Sea and the Baltic Sea. The project investigated trends in the concentrations of nutrients, plankton blooms, macro-benthos, and oxygen. For that purpose, historical data and sedimentological values were analysed too. The coupled modelling of meteorological/hydrographical/biological processes was an important component of the project.

The final report is being prepared. Preliminary results show that the load by nitrate and phosphate has increased drastically; and so has the phytoplankton (biomass).

These results were brought to the attention of the German Bundestag in the hearing "Protection of the North Sea" (1987) and also to the Second International North Sea Conference (London, 1987). The ministers agreed in London to reduce by $50 \%$ the input of hazardous substances and nutrients in the North Sea by 1995, based on the figures of 1985. This is being done for precautionary reasons. Consequently, the Minister für Umwelt, Naturschutz und Reaktorsicherheit (Minister for the Environment, Conservation of Nature and Nuclear Safety) has recently submitted a ten-point list of measures to the environmental committee of the German Bundestag aiming at reducing input of pollutants in the North Sea by half, if possible before 1995. Phosphate and nitrate inputs from local sewage treatment plants are to be limited by means of tightening pertinent 
regulations as of 1989. Nitrate and phosphate input from industrial sources are also to be strictly limited on the basis of supplementary regulations. Programmes aimed at reducing direct input of nutrients into coastal and river-bank areas are to be implemented.

\section{CONCLUSION}

It is important to state that there are other national activities concerning the monitoring or protection of the marine environment, e.g. a scientific programme investigating the input of substances into the sea by the atmosphere (BMU/UBA), or the protection measures taken by the administrations of national parks for the Wadden Seas in the German Bight. However, it would be beyond the scope of this Symposium to go into further details.

The results of the programmes outlined above have reached the first essential stage in determining both the pollution and nutrient load of the North and Baltic Sea. However, it is essential to intensify fundamental and applied research to improve our understanding of the complex processes in the marine ecosystem, in order to perform a sound precautionary protection of the environment.

\section{LITERATURE CITED}

Gerlach, S. A., 1987. Pflanzennährstoffe und die Nordsee - ein Überblick. - Seevögel 8, H. 4, 49-62. Bundesminister für Umweit, Naturschutz und Reaktorsicherheit, 1986. Gemeinsames Bund/LänderMeßprogramm für die Nordsee. - Gewässergütemess. Küstenber. Bundesrepublik Deutschland 1984-1985, 1-194.

Deutsches Hydrographisches Institut, 1987. Überwachung des Meeres. Bericht für das Jahr 1986. DHI, Hamburg, 40 pp.

Deutsches Hydrographisches Institut, 1988. Überwachung des Meeres, Bericht für das Jahr 1986. T. 2: Daten. DHI, Hamburg, 157 pp.

Baltic Marine Environment Protection Commission, 1986. First periodic assessment of the state of the environment of the Baitic Sea area, 1980-1985; General conclusions. - Baltic Sea Environ. Proc. $17 A, 1-53$ 